Ks. Wojciech KAMCZYK*

\title{
MĘCZEŃSTWO I KULT BRACI MACHABEJSKICH W NAUCZANIU ŚW. AUGUSTYNA
}

W drugiej połowie IV w. w Kościele starożytnym nastąpił silny rozwój kultu męczenników, związany często także z kultem ich relikwii. Dużą popularnością cieszyli się ci, którzy oddali życie w imię Chrystusa, bohaterzy lokalnego Kościoła, jak i postacie otaczane czcią w większości wspólnot chrześcijańskich ${ }^{1}$. Kult męczenników stanowił ważny element integracji lokalnej społeczności, a także doskonały impuls do nauczania pasterskiego. Wytrawni duszpasterze potrafili umiejętnie ,wykorzystać" go w celu zbudowania wierzących, dawania zachęt czy wskazania ideałów. Gdy „brakowało” lokalnych ,idoli”, poszukiwano postaci godnych czci w innych wspólnotach, sięgano do postaci biblijnych, zdarzało się nawet, że były to postacie ze Starego Testamentu.

Święty Augustyn w Hipponie również starał się włączyć kult męczenników w lokalne duszpasterstwo i w swoje nauczanie. W zbiorze jego homilii znajdujemy całe cykle mów poświęconych męczennikom: św. Janowi Chrzcicielowi, św. Wawrzyńcowi, św. Szczepanowi i innym². Na uwagę zasługują także trzy kazania (Sermones 300, 301,301a $\mathrm{a}^{3}$ ) stanowiące świadectwo kultu w Hipponie braci Machabejskich, postaci i męczenników starotestamentalnych. W niniejszym artykule chciałbym postawić pytanie o to, w jaki sposób Augustyn uzasadniał ów kult i obchód uroczystości poświęconej bohaterom Starego Testamentu? Skąd jej obchód w starożytnej Afryce? Jakie duszpasterskie motywy przyświecały obchodom tej uroczystości? Jakie tematy teologiczne i problemy pastoralne wiązał z ich wspomnieniem biskup Hippony? Podstawą niniejszego opracowania są wspomniane wcześniej homilie wygłoszone z okazji tychże obchodów. Pomocą będą służyć także wybrane wzmianki o braciach Machabejskich, znajdujące się w innych dziełach Doktora łaski.

\footnotetext{
* Ks. dr Wojciech Kamczyk - adiunkt w Katedrze Teologii Patrystycznej i Historii Kościoła na Wydziale Teologicznym Uniwersytetu Śląskiego w Katowicach; e-mail: x.wk@wp.pl.

${ }^{1}$ Por. P. Brown, Kult świętych. Narodziny i rola w chrześcijaństwie łacińskim, tłum. J. Partyka, Kraków 2007, 1-6.

${ }^{2}$ Tom 33 serii Nuova Biblioteca Agostiniana zawiera zbiór mów św. Augustyna dedykowanych świętym, zwłaszcza męczennikom (NBA 33, Roma 1986).

${ }^{3}$ Por. Augustinus Hipponensis, Semones 300-301a, NBA 33, 448-489.
} 
1. Chrześcijański kult braci Machabejskich. W De civitate Dei, wypowiadając się na temat Ksiag Machabejskich, autor pisze:

„Żydzi nie uważają ich za kanoniczne, ale Kościół uznaje, a to ze względu na opisy okrutnych i podziwu godnych cierpień pewnych męczenników, którzy jeszcze przed wcieleniem się Chrystusa aż do śmierci walczyli o prawo Boże i znieśli najcięższe i najstraszliwsze katusze"4.

Do rozwoju kultu braci Machabejskich jako męczenników w starożytnym Kościele przyczyniła się, jak uważa Michał Wojciechowski, szczególnie Czwarta Księga Machabejska, będąca poza zbiorem ksiąg kanonicznych w naszym współczesnym rozumieniu ${ }^{5}$. Sam Augustyn twierdzi, że stało się to dzięki opisom ich męczeństwa, ale trudno ustalić, czy odwoływał się do ksiąg uznawanych obecnie za kanoniczne, uwzględniając znajdujący się w nich tekst, czy też znana mu była i brana przez niego pod uwagę tzw. Czwarta Księga Machabejska ${ }^{6}$. To w niej podkreślony zostaje moralny walor męczeńskiego świadectwa wiary braci i ich matki. Nic jednak nie wskazuje na jego chrześcijański charakter, podobnie jak nie można w niej znaleźć żadnych informacji o czci, jaką tychże męczenników otaczano ${ }^{7}$.

Podstawowym miejscem kultu była Antiochia nad Orontesem, gdzie miały znajdować się grób i relikwie wspomnianych męczenników. Narodziny tej szczególnej czci u chrześcijan przypadają prawdopodobnie na IV w., a więc na czas, gdy w całym cesarstwie rozwijał się kult martyrologiczny ${ }^{8}$. Sam Augustyn daje świadectwo o kulcie braci Machabejskich, którego źródła dostrzega właśnie w Antiochii:

„Uważa się, że bazylika świętych Machabejczyków znajduje się w Antiochii, w tym mieście mianowicie, które nazywa się tak od imienia władcy, który ich

${ }^{4}$ Tenże, De civitate Dei XVIII 36, ed. B. Dombard - A. Kalb, CCL 48, Turnholti 1955, 632: „Quos non Iudaei, sed Ecclesia pro canonicis habet propter quorumdam martyrum passiones vehementes atque mirabiles, qui, antequam Christus venisset in carne, usque ad mortem pro Dei lege certaverunt et mala gravissima atque horribilia pertulerunt”, tłum. W. Kornatowski: Święty Augustyn, O Państwie Bożym, t. 2, Warszawa 1977, 361; por. M. Wojciechowski, Czwarta Księga Machabejska. Żydowski traktat stoicki o potędze rozumu udowodnionej przez męczeństwo. Wprowadzenie, w: M. Wojciechowski, Apokryfy z Biblii greckiej, Rozprawy i Studia Biblijne 8, Warszawa 2001, 109.

${ }^{5}$ Por. Wojciechowski, Czwarta Księga Machabejska, s. 109.

${ }^{6}$ Por. tamże, s. 109-110.

${ }^{7}$ Środowiskiem powstania tejże księgi był zapewne judaizm hellenistyczny, samo miejsce akcji pozostaje jednak sporne i nie wiadomo czy była to Jerozolima, czy raczej Antiochia Syryjska, gdzie rozwinął się kult męczenników Machabejskich. Autor okazuje większe zainteresowanie wywodom filozoficznym niż samemu kultowi męczenników. Jej celem wydaje się być raczej próba przedstawienia poglądów żydowskich językiem greckiej filozofii; por. M.-F. Baslez, Prześladowania w starożytności. Ofiary, bohaterowie, męczennicy, thum. E. Łukaszczyk, Kraków 2009, 197; Wojciechowski, Czwarta Księga Machabejska, s. 99-101.

${ }^{8}$ Por. M. Ożóg, Przejęcie przez chrześcijan antiocheńskiego martyrium Machabeuszy, PrzRel $228(2008) \mathrm{nr} 2,7$. 
prześladował. Uznano oczywiście, że król Antioch [był] bezbożnym prześladowcą i pamiątkę ich męczeństwa obchodzi się w Antiochii, aby [w ten sposób] wspólnie wybrzmiewało imię prześladowcy i pamięć zwycięzców ${ }^{9}$. Tę bazylikę posiadają chrześcijanie, przez chrześcijan została wybudowana. My zaś świętujemy ich pamiątkę, która [w ten sposób] powinna być obchodzona, my [ja] posiadamy: u nas ich mękę tysiące męczenników po całej ziemi naśladują" "10.

Omawiając źródła i początki czci braci Machabejskich, Augustyn popełnia jednak kilka błędów. Odnosi bowiem miejsce kultu do miasta noszącego nazwę prześladowcy ${ }^{11}$. Choć zbieżność jest tu widoczna, to mylnie została odczytana przez biskupa Hippony. Antiochię nad Orontesem założył Seleukos I Nikator, jeden z dowódców Aleksandra Wielkiego, w maju 300 r. prz. Chr., nadając jej nazwę od imienia swojego ojca Antiocha. Znane były również i inne wersje dotyczące założenia miasta ${ }^{12}$. Z pewnością jednak jego założycielem nie był Antioch IV Epifanes, wymieniany w Księgach Machabejskich jako prześladowca Machabeuszy, co miało mieć miejsce ok. 168 r. przed Chrystusem ${ }^{13}$. Skąd Augustyn zaczerpnął swoją wersję - trudno powiedzieć ${ }^{14}$.

Drugą watpliwą informacja, którą wykorzystuje Augustyn, jest fakt wybudowania bazyliki na cześć Machabeuszy przez chrześcijan, zaś zignorowanie ich czci przez Żydów. Wielu badaczy przychyla się do hipotezy, iż kult braci Machabejskich zapoczątkowali w Antiochii właśnie wyznawcy judaizmu ${ }^{15}$. Choć trudno uzasadnić go doktrynalnie, Żydzi bowiem zwykle nie łączyli grobowców z miejscami kultu, to wydaje się wielce prawdopodobne, że w Antiochii tak właśnie było. Znajdowała się tam synagoga, w której gromadzili się Żydzi, a gdzie pielgrzymowało także wielu innych czcicieli, gdyż słynęła ona jako miejsce licznych uzdrowień, których przyczyną miał być grób, faktyczny

${ }^{9}$ Dosłownie „ukoronowanych”, Augustyn określał w ten sposób śmierć męczenników, podkreślając jej godny chwały charakter.

${ }^{10}$ Augustinus Hipponensis, Sermo 300, 6, NBA 33, 454: „Sanctorum Machabaeorum basilica esse in Antiochia praedicatur: in illa scilicet civitate, quae regis ipsius persecutoris nomine vocatur. Antiochum quippe regem persecutorem impium pertulerunt, et memoria martyrii eorum in Antiochia celebratur; ut simul sonet et nomen persecutoris, et memoria coronatoris. Haec basilica a Christianis tenetur, a Christianis aedificata est. Eorum ergo memoriam celebrandam nos habemus, nos tenemus: apud nos passiones eorum millia per orbem terrarum sanctorum martyrum imitata sunt", tłum. własne.

${ }^{11}$ Por. M. Rampolla, Martyre et sépulture des Machabées, trad. T.-P.-H. Lemonnier, „Revue de l'art chrétien" 42 (1899) 296.

${ }^{12}$ Por. Ożóg, Przejęcie przez chrześcijan antiocheńskiego martyrium Machabeuszy, s. 5; P. Filipczak, Antiochia nad Orontesem. Funkcjonowanie miasta i życie jego mieszkańców w IV wieku, w: Świat rzymski w IV wieku, red. P. Filipczak - R. Kosiński, Kraków 2015, 259.

${ }^{13}$ Por. Ożóg, Przejęcie przez chrześcijan antiocheńskiego martyrium Machabeuszy, s. 4.

${ }^{14}$ Por. tamże, s. 10-11.

${ }^{15}$ Por. J. Naumowicz, Chrześcijański kult męczenników machabejskich w Antiochii, w: Byzantina Europaea. Ksiegga jubileuszowa ofiarowana profesorowi Waldemarowi Ceranowi, red. M. Kokoszko - M.-J. Leszka, Łódź 2007, 431. 
bądź tylko symboliczny, braci Machabejskich i ich matki ${ }^{16}$. W 2. poł. IV w. synagoga ta przejęta została przez chrześcijan, a kult mający w niej miejsce zaadaptowany do realiów chrześcijańskich ${ }^{17}$.

Faktem jest jednak kult, którym cieszyli się męczennicy Machabejscy nie tylko na Wschodzie, w Antiochii, lecz również na Zachodzie, w tym także w Afryce. Augustyn mówi bowiem o obchodach pamiątki ich męczeństwa, którą posiada Kościół i którą powinien kultywować. Męczeństwo siedmiu braci ma być nie tylko wspominane i obchodzone, lecz również naśladowane przez chrześcijan, co w szczególny sposób zdaje się uwydatniać w swoim nauczaniu. Wygłoszonych z tej okazji kilka homilii potwierdza fakt, że w Afryce Północnej, podobnie jak w wielu innych regionach Kościoła, oddawano im cześć, wspominając ich męczeństwo 1 sierpnia ${ }^{18}$.

2. Elementy polemiki z judaizmem. Ponieważ siedmiu braci Machabejskich oraz ich matka są bohaterami ksiąg Starego Testamentu, Augustyn słusznie stara się zbić zarzuty o przywłaszczenie sobie przez chrześcijan ich kultu. Dlatego w zaimprowizowanym dialogu próbował wykazać, że członkowie narodu wybranego nie doceniają ich własnych męczenników:

„Wystąpił pewien Żyd i mówi do nas: Dlaczego naszych męczenników zaliczacie do waszych? Z jakiego powodu ich pamiątkę obchodzicie? Przeczytajcie ich wyznanie: sprawdźcie, czy są wyznawcami Chrystusa? Odpowiemy mu: ty także jesteś jednym z tych, którzy nie uwierzyli w Chrystusa, i odłamani od drzewa oliwnego, podobni do dzikiej oliwki, pozostają uschli na zewnątrz (por. Rz 11, 17); cokolwiek byś mówil, jesteś także jednym ze zdrajców?"19.

Augustyn nie przybliża postaci swego rozmówcy, być może dlatego, że nie chodziło mu wcale o konkretną osobę, a sam dialog w całości został przez niego skomponowany na potrzeby homilii. Istota jednak tego zabiegu było wskazanie na możliwą argumentację ze strony wyznawców judaizmu, podważającą

${ }^{16}$ Por. Ożóg, Przejęcie przez chrześcijan antiocheńskiego martyrium Machabeuszy, s. 4-8.

${ }^{17}$ Przyczyny takiego stanu rzeczy mogą być różne. Niektórzy badacze uważają że stało się tak z powodu szerzącego się kultu braci Machabejskich i licznych uzdrowień, które miały w związku z tym miejsce. Chrześcijańscy władcy i biskupi, nie mogąc sobie poradzić z tym faktem, postanowili przejąć martyrium, nadając mu chrześcijański charakter, gdyż sami bracia Machabejscy i tak cieszyli się dużym poważaniem wśród chrześcijan i uznawani byli za pierwowzór chrześcijańskich męczenników; por. Ożóg, Przejęcie przez chrześcijan antiocheńskiego martyrium Machabeuszy, s. 8; Filipczak, Antiochia nad Orontesem, s. 279; Naumowicz, Chrześcijański kult męczenników machabejskich w Antiochii, s. 441.

${ }^{18}$ Por. Naumowicz, Chrześcijański kult męczenników machabejskich w Antiochii, s. 435-438; Rampolla, Martyre et sépulture des Machabées, s. 298.

${ }^{19}$ Augustinus Hipponensis, Sermo 300, 3, NBA 33, 450: „Existit aliquis Iudaeus, et dicit nobis: Quomodo istos nostros, vestros martyres computatis? Qua imprudentia eorum memoriam celebratis? Legite confessiones eorum: attendite si confessi sunt Christum. Cui respondemus: Vere quia unus es ex eis qui in Christum non crediderunt, et fracti de oliva, oleastro succedente, foris aridi remanserunt (por. Rz 11, 17); quid dicturus es unus ex perfidis?”, tłum. własne. 
sensowność chrześcijańskiego kultu starotestamentalnych postaci, nieznających Chrystusa i niewyznających wiary w Niego. Podjęcie tego wątku wskazuje na obecność wyznawców religii mojżeszowej w Afryce Północnej, a także na ich wpływ na wyznawców Chrystusa ${ }^{20}$.

Pierwszy, podstawowy argument, przywoływany przez biskupa Hippony, jest antyjudaistyczny. Deprecjonuje swojego rozmówcę, wskazując na jego przynależność do grona tych, którzy sami odrzucili Chrystusa ${ }^{21}$ i po dziś dzień nie rozumieją wydarzeń Starego Testamentu:

„Zobacz więc niewiernych ojców twoich, Żydów, lecz w złu [zobacz] twoich braci! Zobacz, co o takich mówi Apostoł Paweł: «Aż do czasów obecnych, jak długo czyta się Mojżesza, położona jest na ich sercach zasłona» (2Kor 3, 14)"’22.

Idąc za myślą Pawłową, Augustyn uważa, że na umysłach i sercach Żydów położona jest zasłona, niepozwalająca im we właściwy sposób odczytać ich własnego prawa, które przecież zapowiadało nadejście Mesjasza. Brak umiejętności właściwego odczytania i prawa, i proroctw skutkuje także nieumiejętnością odczytania przesłania samych męczenników Machabejskich. Choć przynależą oni do czasów Starego Testamentu, to jako nieliczni potrafili opowiedzieć się za wiernością Bogu i wiernością przepisom prawa. Żydzi jednak odrzucili Tego, który wypełnił Prawo. Ci, choć nigdy Go nie poznali, samą wiernością Prawu złożyli wyznanie wiary. W tym sensie więc można uznać ich za chrześcijan ${ }^{23}$.

„Komu służyły języki wyznających, temu posłużyło pióro (dosł. trzcina) prawdę piszących. Jakże będziecie mogli zrozumieć pióro (dosł. trzcinę) Mojżesza wy, którzy na trzcinie ocet przywiązaliście? Nie możecie w końcu pić wina Tego, któremu wtedy bluźnierczo podawaliście ocet do picia"24.

${ }^{20}$ Żydzi w Afryce Rzymskiej stanowili społeczność dość zasymilowaną z mieszkańcami kontynentu, jednak mieli spory wpływ na życie społeczne. Zarzucano im często prozelityzm, a także czary i magię. Chrześcijanie nierzadko korzystali z ich usług, zdarzali się i tacy, którzy chcieli żyć według Prawa Mojżeszowego; por. S. Adamiak, Żydzi w rzymskiej Afryce Pólnocnej, BPTh 7/1 (2014) 102-103.

${ }^{21}$ Jest ono bezpośrednim skutkiem grzechu pychy, jaki dotknął Żydów. Ich logika jest „,cielesna”, zakorzeniona w tym, co doczesne; por. M. Terka, Nauczanie św. Augustyna o Żydach w świetle „Enarrationes in Psalmos”, VoxP 32 (2012) t. 57, 688-689.

${ }^{22}$ Augustinus Hipponensis, Sermo 300, 3, NBA 33, 450: „Vide ergo de infidelibus Iudaeis patribus tuis, sed in malo fratribus tuis, vide quid de talibus dicat apostolus Paulus. «Usque nunc quamdiu legitur Moyses, velamen super corda eorum positum est» (2Kor 3, 14)”, thum. własne.

${ }^{23}$ Por. tamże 300, 6, NBA 33, 454. Za takowych uznawani byli już przez wcześniejszych Ojców Kościoła: Cypriana z Kartaginy, Hipolita Rzymskiego oraz Jana Chryzostoma. Grzegorz z Nazjanzu nie wspomina o ich Antiocheńskim kulcie, ale wzmiankuje o ich chrześcijańskim święcie i stara się uzasadnić ich chrześcijańską cześć; zob. Naumowicz, Chrześcijański kult męczenników machabejskich w Antiochii, s. 435-436.

${ }^{24}$ Augustinus Hipponensis, Sermo 300, 5, NBA 33, 454: „Cui servierunt linguae confitentium, ei servivit calamus vera scribentium. Vos calamum Moysi quomodo intellegere poteritis, qui in 
Augustyn odwoływał się również do oddzielenia Żydów od stołu Pańskiego. Dokonał tego, posługując się porównaniem i grą słów jednocześnie. „Calamus” (dosł. trzcinę) utożsamianą tutaj z piórem służącym do zapisywania, zestawił z „calamus” - trzciną użytą do podania Chrystusowi wiszącemu na krzyżu octu do picia. W pierwszym wypadku służy ona zapisaniu prawdy o wydarzeniach, które związane były z męczeństwem braci, w drugim do szyderczego podania napoju, który w zamierzeniu oprawców nie miał służyć ugaszeniu pragnienia. I w tym miejscu sam Augustyn nie jest do końca wierny opisom ewangelicznym, gdzie nie ma mowy o tym, że to sami Żydzi podawali Jezusowi ocet. Bardziej prawdopodobne, że byli to żołnierze rzymscy (por. J 19, 29-30) $)^{25}$. Kaznodzieja widzi jednak w tym akcie bluźnierstwo i odrzucenie Chrystusa, a co za tym idzie, odrzucenie wszystkiego, co ma z Nim związek. Fakt odrzucenia kultu Machabeuszy przez Żydów dowodzi większego związku męczenników z Chrystusem i chrześcijanami ${ }^{26}$.

Jak można zauważyć, polemika Augustyna z wyznawcami judaizmu w kwestii kultu braci Machabejskich opierała się na fakcie odrzucenia przez nich Chrystusa i samej czci braci Machabejskich. Choć wśród samych Żydów w Antiochii mogli cieszyć się dużą popularnością, to w tej kwestii Augustyn zdaje się iść za głównym nurtem współczesnego mu judaizmu, który odrzucał kanoniczność Ksiag Machabejskich, a więc i samą wartość wyznania wiary jej bohaterów. To nadawało według biskupa Hippony wartość samemu męczeństwu i pomagało w adaptacji kultu ich męczeństwa jako pośredniego pomiędzy judaizmem a wyznaniem wiary chrześcijańskiej.

3. Uzasadnienie chrześcijańskiego kultu Machabeuszy. Samo jednakże odrzucenie Machabeuszy przez społeczność żydowską nie wystarczało jako argument za ich kultem wśród chrześcijan. Musiał zdawać sobie z tego sprawę

calamo acetum ligastis? Utinam aliquando vinum eius bibatis, cui adhuc blasphemando acetum propinatis", tłum. własne.

${ }^{25} \mathrm{Z}$ grona Ewangelistów o podaniu Jezusowi octu mówi tylko Jan. Natomiast Mateusz i Marek mówią o winie zaprawionym goryczą, zaś Łukasz w ogóle o tym fakcie nie wspomina. Wyrok wykonywali i skazańców pilnowali rzymscy żołnierze, broniąc dostępu do ukrzyżowanych nie tylko zwolennikom, ale i ich przeciwnikom, por. Mt 27, 48; Mk 15, 36; Łk 23, 36; J 19, 28-30.

${ }^{26}$ Żydzi odrzucili także same Księgi Machabejskie, choć jeszcze w czasach Chrystusa były wysoko cenione i przez wielu uznawane za natchnione. Proces ten nastąpił prawdopodobnie po roku 70., a więc po zburzeniu świątyni w Jerozolimie, kiedy zaczęło zanikać kapłaństwo starozakonne, zaś władzę duchową w judaizmie przejęli faryzeusze. Wykluczyli oni przede wszystkim Księgi Machabejskie oraz inne, które albo nie zostały spisane językiem świętym (klasycznym językiem hebrajskim lub aramejskim), nie powstały w ziemi palestyńskiej, albo nie były zgodne z Prawem Mojżeszowym. Powszechnie uważa się, że oficjalne ustalenie kanonu miało miejsce na synodzie w Jabne (Jamnia) ok. 90 r., ale niektórzy uczeni poddają ten fakt w wątpliwość (por. J. Homerski, Kanon Ksiag Świętych, w: Wstęp ogólny do Pisma Świętego, red. J. Szlaga, Warszawa 1986, 79-80; R. Rubinkiewicz, Jabne, EK VII 638-639; W.-J. Harrgington, Klucz do Biblii, tłum. J. Marzęcki, Warszawa 1982, 43). 
Augustyn, który głosząc swoje homilie, starał się wskazać na wartość ich męczeństwa także z chrześcijańskiego punktu widzenia:

„Sława Machabejczyków sprawia, że ten dzień jest dla nas świąteczny. Kiedy czytano, nie tylko słyszeliśmy o ich niezwykłych cierpieniach, lecz również je widzieliśmy i podziwialiśmy. Te wydarzenia miały miejsce dawniej, przed wcieleniem, przed męką Pana i Zbawiciela naszego Jezusa Chrystusa. Należeli do owego pierwszego ludu, do którego należeli też prorocy, którzy obecne rzeczy przepowiedzieli. I niech ktoś nie uważa, że nie istniał żaden lud Boży zanim zaistniał lud chrześcijański. Wręcz przeciwnie, należy tak mówić, aby przedstawić prawdę, a nie zwyczajowe nazwy, bowiem [już] wtedy ów lud był chrześcijański. Nie rozpoczął być ludem Chrystusa dopiero po Jego męce, lecz ów lud został zrodzony z Abrahama. Dał temu świadectwo sam Pan, mówiąc: «Abraham pragnął ujrzeć mój dzień; zobaczył i uradował się» (J 8, 56). A więc z Abrahama zrodzony był ów lud, który służył w Egipcie, i który został wyzwolony potężną ręką przez Mojżesza, sługę Bożego, z domu niewoli, wyprowadzony przez Morze Czerwone dzięki rozstępującym się falom, doświadczany na pustyni, poddany prawu, osiedlony w królestwie. W nim, jak powiedziałem, istnieli prorocy, w nim owi męczennicy zasłynęli. Chociaż jeszcze nie umarł Chrystus, lecz Chrystus, mający dopiero umrzeć, uczynił ich męczennikami”"27.

Podstawą kultu braci Machabejskich u chrześcijan jest ich przynależność do ludu Bożego. Taki lud nie powstał równocześnie z pojawieniem się chrześcijaństwa, ale swoimi początkami sięga już osoby Abrahama, z którego został zrodzony. Tenże lud był niewolnikiem w Egipcie i został uwolniony ręką Mojżesza. $\mathrm{Z}$ tego ludu wywodzili się również prorocy, którzy wiele rzeczy zapowiedzieli na temat Chrystusa. Do tego ludu należeli więc także sami bracia Machabejscy, gdyż byli wyznawcami i obrońcami Prawa Mojżeszowego. O tym, że jest to także lud Chrystusa, nie powinny przesądzać stosowane nazwy, ale świadectwo Pisma, a to ustami samego Chrystusa podaje, że lud ten bierze początek właśnie od Abrahama. Chrystus nie umarł wtedy, ale jako mający zbawić świat, był obecny w swoim ludzie, a wyznających wiarę uczynił męczennikami.

${ }^{27}$ Augustinus Hipponensis, Sermo 300, 1, NBA 33, 448: „Istum diem nobis solemnem gloria Machabaeorum fecit: quorum mirabiles passiones, cum legerentur, non solum audivimus, sed etiam vidimus et spectavimus. Olim ista gesta sunt, ante incarnationem, ante passionem Domini et Salvatoris nostri Iesu Christi. In primo populo illo exstiterunt, in quo Prophetae exstiterunt, qui haec praesentia praedixerunt. Nec quisquam arbitretur, antequam esset populus Christianus, nullum fuisse populum Deo. Imo vero, ut sic loquar, quemadmodum se veritas habet, non nominum consuetudo, christianus etiam ille tunc populus fuit. Neque enim post passionem suam coepit habere populum Christus: sed illius populus erat ex Abraham genitus, cui perhibens testimonium ipse Dominus ait: «Abraham concupivit videre diem meum; et vidit, et gavisus est» $(\mathrm{J} 8,56)$. Ergo ex Abraham natus est ille populus, qui servivit in Aegypto, et qui manu potenti per Moysen famulum Dei de domo servitutis liberatus, per mare Rubrum fluctibus descendentibus ductus, in eremo exercitatus, legi subditus, in regno collocatur. Unde, sicut dixi, exstiterunt Prophetae, inde isti martyres floruerunt. Nondum quidem erat mortuus Christus: sed martyres eos fecit moriturus Christus", thum. własne. 
„Męczennicy wyznali Go [tzn. Chrystusa] jawnie, zaś Machabejczycy wówczas wyznali Go w tajemnicy. Ci zginęli za Chrystusa objawionego w Ewangelii, tamci zginęli w imię Chrystusa ukrytego w prawie. Do Chrystusa należą jedni i drudzy, Chrystus wspierał jednych i drugich, gdy staczali walkę, Chrystus ukoronował jednych i drugich"28.

Kaznodzieja zwracał uwagę na różnicę w wyznaniu wiary w Chrystusa pomiędzy męczennikami chrześcijańskimi czasów po Chrystusie, a męczennikami Machabejskimi. Ci pierwsi, kiedy zadawano im pytania, wyznali wprost swoją wiarę i przywiązanie do Chrystusa. Znali Go jako objawionego w Ewangelii. Bracia Machabejscy wyznali również Chrystusa, ale uczynili to w tajemnicy. Nie znali Go bezpośrednio, ale oddali życie za prawo, w którym Chrystus był ukryty. Chrześcijanie mają prawo tak sądzić, gdyż prawdy Nowego Testamentu były ukryte w Starym Testamencie, a Nowy Testament jest objawieniem się Testamentu Starego ${ }^{29}$.

Biskup zatem śmiało mówi, że zarówno męczennicy chrześcijańscy, jak i męczennicy Machabejscy, przynależą do Chrystusa, który wspierał mężną walkę jednych i drugich. Wreszcie to sam Chrystus ukoronował jednych i drugich $^{30}$. Stanowią oni orszak otaczający Mesjasza jako możnego władcę, gdzie jedni ze sług poprzedzają idącego Pana, drudzy postępują za $\mathrm{Nim}^{31}$. Z tego właśnie powodu Augustyn ośmiela się stwierdzać:

„Gdy więc podziwiacie owych męczenników, to najpierw Waszej Miłości zalecam, abyście nie wątpili, że oni byli chrześcijanami. Byli chrześcijanami, lecz antycypowali w nazwie chrześcijan, która później się rozpowszechniła"32.

Wniosek, że męczennicy Machabejscy byli chrześcijanami, nie powinien być poddawany w wątpliwość. Sami wprost nie byli nazywani w ten sposób, bo nazwa ta rozpowszechniła się o wiele później, ale mieli w niej udział przez swoją postawę i wierność prawu Mojżeszowemu, które wypełniło się w Chrystusie $^{33}$. Nie byli oni również zmuszani do odrzucenia imienia Chrystusa, jak

${ }^{28}$ Tamże 300, 5, NBA 33, 452: „Ipsum martyres in manifesto confessi sunt, quem tunc Machabaei in occulto confessi sunt: mortui sunt isti pro Christo in Evangelio revelato; mortui sunt illi pro Christi nomine in lege velato. Christus habet utrosque, Christus pugnantes adiuvit utrosque, Christus coronavit utrosque", thum. własne.

${ }^{29}$ Por. tamże 300, 3, NBA 33, 450.

${ }^{30}$ Augustyn często mówi o „ukoronowaniu” w odniesieniu do męczenników. Wyraża w ten sposób nagrodę, jaką jest królestwo niebieskie i chwała, którą są otaczani oraz ich udział w życiu samego Boga; por. T. Kaczmarek, ,, Seges Ecclesiae”. Eklezjalny wymiar męczeństwa w nauczaniu św. Augustyna, Toruń 2010, 160; W. Kamczyk, Kult świętego Szczepana w duszpasterstwie biskupa Augustyna z Hippony, SSHT 49/2 (2016) 314.

${ }^{31}$ Por. Augustinus Hipponensis, Sermo 300, 5, NBA 33, 452.

${ }^{32}$ Tamże 300, 2, NBA 33, 448: „Hoc ergo in primis commendandum est caritati vestrae, ne, cum illos martyres admiramini, putetis non fuisse christianos. Christiani fuerunt: sed nomen Christianorum postea divulgatum factis antecesserunt", thum. własne.

${ }^{33}$ Warto w tym miejscu zwrócić uwagę na fakt, że to właśnie w Antiochii Syryjskiej, gdzie 
miało to miejsce w przypadku późniejszych męczenników, ale cierpieli za wierność prawu ${ }^{34}$. Ich wyznanie było więc okryte tajemnicą zasłony, jak to ma miejsce przy czytaniu Starego Testamentu, a która to zasłona zdjęta zostaje przez Chrystusa, kluczem zaś do niej jest Jego krzyż ${ }^{35}$. Augustyn powołuje się tu na słowa samego Chrystusa, mówiącego, że wierzący słowom Mojżesza powinni być jednocześnie ufać naukom i dziełom Chrystusa (por. J 5, 46) ${ }^{36}$.

4. Szczególna wartość postawy matki siedmiu braci. Wydaje się, że szczególne miejsce w całym „męczeńskim” wydarzeniu Augustyn przypisywał matce siedmiu braci. O ile bowiem sami bracia mogli stanowić wzór dla mężczyzn, o tyle matka stanowiła doskonały przykład postawy dla kobiet:

„Niech uczą się kobiety od owej matki takiej cierpliwości, nadzwyczajnej cnoty, którą ona nauczyła się służyć swoim synom. Nauczyła się posiadać to, czego nie bała się utracić. Oni pojedynczo [cierpieli], będąc doświadczani, ona cierpiała, oglądając każdego [z nich]. Matka siedmiu męczenników - siedem razy uczyniona męczennica; nieoddzielona od synów oglądaniem, z synami złączona umieraniem. Widziała wszystkich, kochała wszystkich. Nosiła w oczach, jak i w ciele wszystkich. I nie tylko nie odstraszała, lecz nawet zachęcała [do męczeństwa]"37.

Wczesnochrześcijańska tradycja widziała w matce siedmiu braci Machabejskich szczególny przykład cnót i męstwa, które okazało się w postawie wspierania decyzji o oddaniu życia własnych synów. Tradycyjnie przypisywano jej imię Aszmunit i uznawano za świętą, wraz z umęczonymi synami oraz starcem Eleazarem ${ }^{38}$. Augustyn w swych homiliach nie przytacza tego imienia, lecz potwierdza kult, który miał miejsce w Antiochii ${ }^{39}$.

Kaznodzieja podkreśla heroizm, jaki dostrzec można w postawie matki. Wynika on z faktu pokonania własnych matczynych odruchów, które skłaniałyby ją do ocalenia za wszelką cenę życia własnych dzieci. Tak postąpiłoby wielu ludzi i nie byłoby to niczym złym. Matka braci Machabejskich skłonna

szerzył się chrześcijańskich kult braci Machabejskich, po raz pierwszy nazwano uczniów Chrystusa chrześcijanami (por. Dz 11, 26).

${ }^{34}$ Por. tamże, NBA 33, 448-450.

${ }^{35}$ Por. tamże 300, 3, NBA 33, 450.

${ }^{36}$ Por. tamże 300, 5, NBA 33, 452-454.

37 Tamże 300, 6, NBA 33, 454: „Discant feminae, de matris illius tanta patientia, ineffabili virtute; quae noverat servare filios suos. Habere noverat, quae perdere non timebat. Isti in se singuli sentiendo, illa videndo in omnibus passa est. Facta mater septem Martyrum, septies martyr: a filiis non separata spectando, et filiis addita moriendo. Videbat omnes, amabat omnes. Ferebat in oculis, quod in carne omnes; nec solum non terrebatur, sed etiam exhortabatur", thum. własne.

${ }^{38}$ Por. Ożóg, Przejęcie przez chrześcijan antiocheńskiego martyrium Machabeuszy, s. 10.

${ }^{39}$ Budynek, w którym miały znajdować się relikwie braci Machabejskich, nazywano kościołem św. Aszmunit, choć pierwotnie miała to być synagoga; por. Ożóg, Przejęcie przez chrześcijan antiocheńskiego martyrium Machabeuszy, s. 8. 
jednak była do postawy niezrozumiałej, ale heroicznej, zachęcała własnych synów do wierności Bogu, widząc w męczeńskiej śmierci ogromną wartośćc ${ }^{40}$. Prawdziwe życie oznaczało oddanie życia i do takiej postawy miała zachęcać bohaterska kobieta ${ }^{41}$.

„Bogatsza dzięki cnotom niż dzięki wydaniu na świat potomków. Widząc walczących, sama w nich wszystkich walczyła i we wszystkich odnoszących zwycięstwo sama zwyciężała"42.

Męstwo matki ocenione zostaje bardzo wysoko. Walka jej synów, wierność i cnota stają się zaletami przypisywanymi jej samej. W odważnej postawie zachęcania i umacniania w męstwie mówca dostrzegał ogromną wartość i zaletę. Jej zwycięstwo było o wiele większe niż zwycięstwo odnoszone przez jej synów. O jej bogactwie stanowiła nie liczba potomków, ale cnoty, jakimi się odznaczała, a które ujawniły się w momencie próby.

Ta postawa Aszmunit porównana zostaje do Matki Kościoła:

„Jedna kobieta, jedna matka, podobnie jak i nam przed oczami staje jedna święta Matka Kościół, zachęcająca wszędzie swoich synów, aby oddawali życie w to imię, z którego ich poczęła i porodziła. W ten sposób na wypełniony krwią męczenników świat przez rozrzucone ziarno rozkrzewił się zasiew Kościoła"^33.

Dla kaznodziei matka braci Machabejskich staje się typem Kościoła, matki wielu wierzących i męczenników. Kościół również zachęca do odważnego świadectwa i męczeństwa swoje dzieci, które sam zrodził w momencie chrztu. Świat zostaje wypełniony krwią męczenników. Krew ta zaś staje się jak ziarno rzucone w ziemię prawdziwym, rozkrzewiającym się zasiewem Kościoła ${ }^{44}$. Zabici męczennicy są podobni do duchowych nasion rzuconych w glebę świata, użyźniających ją, pozwalających wzrastać plonom. Ich owocem są rozsiani po całym świecie chrześcijanie ${ }^{45}$.

\footnotetext{
${ }^{40}$ Por. Augustinus Hipponensis, Sermo 301, 1, 1, NBA 33, 458.

${ }^{41}$ Por. tenże, Sermo 300, 7, NBA 33, 454-456; Sermo 301, 1, 1, NBA 33, 458.

${ }^{42}$ Tenże, Sermo 301, 1, 1, NBA 33, 458: „Fecundior virtutibus, quam fetibus: videns certantes,
} in quibus omnibus ipsa certabat; et in omnibus vincentibus ipsa vincebat”, thum. własne.

${ }^{43}$ Tamże: „Una mulier, una mater, quomodo nobis ante oculos posuit unam matrem sanctam Ecclesiam, ubique exhortantem filios suos pro illius nomine mori, de quo eos concepit et peperit? Sic sanguine martyrum impletus orbis praeiactatis seminibus seges Ecclesiae pullulavit”, thum. własne.

${ }^{44}$ Myśl tę, w której krew męczenników porównana zostaje do zasiewu, rozpropagował w chrześcijaństwie Tertulian: „Semen est sanguis Christianorum! (Nasieniem jest krew chrześcijan)" (Tertulianus, Apologeticum 50, 13, ed. E. Dekkers, CCL 1, Turnholti 1954, 171, thum. J. Sajdak: Tertulian, Apologetyk, POK 20, Poznań 1947, 202).

${ }^{45}$ Myśl ta, charakterystyczna dla augustyńskiej teologii męczeństwa, pojawia się wielokrotnie w nauczaniu biskupa Hippony (por. Enarrationes in Ps. 58, 1, ed. E. Dekkers - J. Fraipont, CCL 39, Turnhout 1956, 730; tamże 70(2), 4, CCL 39, 963; tamze 69, 1, CCL 39, 930; tenże, Sermo 280, 6, NBA 33, 104; tenże, Sermo 286, 4, 3, NBA 33, 146; por. Kaczmarek, , Seges Ecclesiae”, s. 206. 
5. Sens męczeństwa braci Machabejskich. Wskazując na znaczenie męczeńskiej śmierci braci Machabejskich, Augustyn przywołuje inne starotestamentalne wydarzenie - wrzucenie trzech młodzieńców do ognistego pieca ${ }^{46}$. Analizując oba wydarzenia, kaznodzieja rozważa:

„Dlaczego tamci zostali wybawieni od ognia, a ci przez ogień zostali strawieni? Czyżby tamtych Bóg wspomógł, a tych opuścił? Ależ nie: a nawet jednych i drugich wspierał; tamtych otwarcie, tych zaś skrycie. Tamci widzialnie zostali wyzwoleni, ci niewidzialnie zostali ukoronowani. Tamci, chociaż zostali wybawieni od śmierci, to jednak pozostali poddani pokusom tego życia. Od ognia wybawieni, [pozostawali] narażeni na [inne] niebezpieczeństwa. Zwyciężywszy jednego tyrana, teraz mający walczyć z diabłem. Bracia moi, rozumujcie jako chrześcijanie. Machabejczycy lepiej i skuteczniej zostali wyzwoleni. W odróżnieniu od owych trzech mężów, którzy pod każdym innym względem pozostawali [wystawieni na pokusy], [spośród Machabejczyków] ona jedna na kuszenie została wystawiona. Następnie z boskiego wyro$\mathrm{ku}, \mathrm{z}$ dala od ukrytych watpliwości, lecz jednak przez sprawiedliwość, Nabuchodonozor zasłużył na nawrócenie, Antioch zasłużył na zatwardziałość. Ten pierwszy znalazł miłosierdzie, drugi pomnożył zuchwałość" ${ }^{47}$.

Według Augustyna, Bóg działał swoją zbawczą mocą w przypadku jednych, jak i drugich. Trzej młodzieńcy zostali wprawdzie wyzwoleni od płomieni, nie pozwoliło im to jednak ustrzec się pokus w dalszym życiu. Chociaż zwyciężają jednego tyrana, ich prześladowcę, wystawieni zostają na prześladowanie ze strony diabła. Bóg ocalił ich tutaj jawnie, co przyczyniło się ostatecznie do nawrócenia ich niedoszłego zabójcy - Nabuchodonozora. W przypadku siedmiu braci nie miało miejsca widzialne, zewnętrzne ocalenie, dokonało się jednak ich ukoronowanie, uwolnienie od wszelkich pokus i obdarowanie życiem wiecznym. To drugie wyzwolenie jest, według kaznodziei, lepsze i skuteczniejsze. Jedynie matka braci Machabejskich została wystawiona na pokusy, ale i ona potrafiła się im oprzeć. W tej sytuacji oprawca nie dostępuje miłosierdzia, lecz pomnaża swoją zuchwałość. Utwierdza się w złu i skazuje na potępienie.

Według biskupa Hippony, męczeństwo braci Machabejskich ma ukazać wartość życia wiecznego i szczęście, jakie wierzący mogą znaleźć w królestwie niebieskim. Choć chrześcijanie doświadczają w tym życiu wielu

${ }^{46}$ Por. Augustinus Hipponensis, Sermo 301, 1, 2, NBA 33, 458.

${ }^{47}$ Tamże 301, 3, 2, NBA 33, 460: ,Quare illi ab ignibus liberantur, isti ab ignibus consumuntur? Ergo illis Deus aderat, hos deseruerat? Absit: imo utrisque adfuit; illis in aperto, istis in occulto. Illos visibiliter liberabat: istos invisibiliter coronabat. Illi quidem de morte liberati sunt; sed in huius vitae tentatione manserunt: ab igne liberati, ad pericula reservati; uno tyranno victo, adhuc certaturi cum diabolo. Fratres mei, sicut christiani intellegite. Machabaei melius et tutius liberati sunt. Ab illis tribus viris, caeteris remanentibus, illa una tentatio superata est: ab istis ista vita finita, quae tota tentatio est. Deinde divino iudicio, occulto procul dubio, sed tamen iusto, Nabuchodonosor meruit converti, Antiochus meruit obdurari. Ille invenit misericordiam, iste auxit superbiam”, thum. własne. 
prześladowań, nieszczęść i upadków, to jednak mogą spodziewać się radości nieba. Niewierzący, grzesznicy, parający się złem, magią czy wróżbiarstwem tylko pozornie cieszą się obecnym życiem. Bóg złudnie pozwala im zażywać rozkoszy doczesnych, dlatego że nie liczą na wieczne ${ }^{48}$. Antioch jest przykładem prześladowcy i grzesznika, którego Bóg pozostawia na tym świecie dla podkreślenia znaczenia tych, którzy są Jemu wierni. Podobny jest w tym do malarza, który potrafi odpowiednio użyć także szkaradnej, czarnej farby, by podkreślić walory pozostałych kolorów. Przypomina także złotnika, który odważa złoto, ocenia jego wartość, odpowiednio dawkuje, by podnieść jego wartość. Bóg posługuje się ludźmi złymi i grzesznikami, by docenić swoje stworzenie i tych, którzy są Jemu wierni ${ }^{49}$.

\section{Męczeństwo braci Machabejskich jako chrześcijańskie widowisko.}

Warty zauważenia jest fakt łączenia obchodu męczeństwa braci Machabeuszy z innym duszpasterskim zagadnieniem. Ujawnia je Augustyn w każdym z kazań przeznaczonych na ich święto już w samym sposobie wspominania ich męczeństwa:

„Sława Machabejczyków sprawia, że ten dzień jest dla nas świąteczny. Kiedy czytano, nie tylko słyszeliśmy o ich niezwykłych cierpieniach, lecz również je widzieliśmy i podziwialiśmy" 50 .

I w innym miejscu, jeszcze jaśniej ujawnia swoje skojarzenia:

„Wielkie widowisko zostało przedstawione oczom naszej wiary. Uszami słyszeliśmy, sercem widzieliśmy matkę spodziewającą się końca tego życia swoich synów. Dalekie jest to od odmiennych próśb zwyczaju ludzkiego" ${ }^{51}$.

Augustyn, nawiązując do sceny męczeństwa braci Machabejskich, stara się ukazać ich bohaterstwo i męczeństwo jako swego rodzaju widowisko. Czynił tak w odniesieniu do wielu innych męczenników i opisów ich męczeństwa. Lektura biblijnego tekstu, choć pozwalająca jedynie zmysłem słuchu wejść w przytaczane zdarzenia, dla słuchaczy ma stać się widowiskiem godnym podziwiania i naśladowania. Zdolne zobaczyć je są oczy wiary ${ }^{52}$. Ten sposób mówienia o wewnętrz-

\footnotetext{
${ }^{48}$ Por. tamże 301, 4, 3, NBA 33, 460-462.

${ }^{49}$ Por. tamże 301, 5, 4, NBA 33, 462-464.

${ }^{50}$ Tenże, Sermo 300, 1, NBA 33, 448: „Istum diem nobis solemnem gloria Machabaeorum fecit: quorum mirabiles passiones, cum legerentur, non solum audivimus, sed etiam vidimus et spectavimus", thum. własne.

${ }^{51}$ Tenże, Sermo 301, 1, 1, NBA 33, 458: „Magnum spectaculum positum est ante oculos fidei nostrae. Aure audivimus, corde vidimus optantem matrem ante se finire istam vitam filios suos: longe contrariis votis consuetudini humanae", thum. własne.

${ }^{52}$ Szerzej na temat duchowych zmysłów i duchowego postrzegania w nauczaniu Ojców Kościoła zob. P. Szczur, Rola „zmystów wiary” w zrozumieniu sakramentów inicjacji chrześcijańskiej wedtug Cyryla Jerozolimskiego, VoxP 34 (2014) t. 61, 297-310; tenże, Rola postrzegania duchowego w nauczaniu katechetycznym Jana Chryzostoma, VoxP 34 (2014) t. 62, 493-504.
} 
nych zmysłach wiary nie jest obcy biskupowi Hippony. Odwołuje się w nim do wewnętrznych przeżyć słuchaczy, zachęcając do zaangażowania całej osoby.

Zamierzenie Augustyna wydaje się w tym miejscu być jasne, chce stworzyć przeciwwagę dla widowisk o charakterze pogańskim, na które jemu współcześni nierzadko uczęszczali ${ }^{53}$. Widowiska teatralne, mimy i pantomimy ${ }^{54}$, walki gladiatorów $\mathrm{w}^{55}$, polowania, widowiska cyrkowe i wyścigi rydwanów ${ }^{56}$ potępiane były przez wielu chrześcijańskich pisarzy ${ }^{57}$, Augustyn nie należał więc tu do wyjątków, próbując, jak wielu jego poprzedników, nie ograniczać się jedynie do pouczeń, zakazów i gróźb, ale proponować w zamian przeżywanie niektórych elementów liturgii, wspominanych wydarzeń biblijnych i innych, jako swego rodzaju chrześcijańskie odpowiedniki przeżyć i widowisk o podłożu pogańskim $^{58}$. Stąd też pojawia się $\mathrm{w}$ jego homiliach terminologia, nawiązująca do oglądania i przeżywania zabaw i uciech właściwych niewierzącym:

„Porównajcie z tym świętym widowiskiem pożądliwości i uciechy teatralne. Tam oczy się kalają, tu serca oczyszczają. Tu widz jest godny pochwały, jeśli stanie się naśladowcą. Tam zaś i widz jest ohydny i naśladowca godny potępienia" ${ }^{\prime \prime}$.

W porównaniu z uciechami teatralnymi, widowiska chrześcijańskie wypadają niezwykle korzystnie. Sam oglądający staje się nie tylko godnym pochwały, ale również odnosi z samego oglądania wymierną korzyść, którą jest oczyszczenie serca. Dodatkowo, jeśli samo widowisko wywrze na nim tak wielkie wrażenie, to może zapalić do działania i naśladowania niezłomnej postawy jego bohaterów. Największym bowiem widowiskiem będzie dla chrześcijan możliwość oglądania niebieskiego Jeruzalem ${ }^{60}$.

${ }^{53}$ Por. tenże, Sermo 301a, 7, NBA 33, 482-484; A. van den Hoek, Execution as Entertainment: The Roman Context of Martyrdom, StPatr 60 (2013) 79.

${ }^{54}$ Teatr w okresie Ojców Kościoła niewiele miał wspólnego z instytucją klasyczną. Rzadko wystawiano w nim antyczne dramaty. Program teatralny wypełniały pantomimy na temat przygód miłosnych antycznych bogów, nie brakowało także scen niemoralnych i seksualnych. Augustyn widział ścisły związek teatru z pogaństwem i jego specyficzne oddziaływanie moralne; por. J. Śrutwa, Widowiska epoki klasycznej w ocenie Kościoła afrykańskiego II-V wieku, RTK 27 (1980) z. 4, 48-49.

${ }_{55}^{5}$ Por. D. Słapek, Sport i widowiska w świecie antycznym, Kraków - Warszawa 2010, 288-293.

${ }^{56}$ Cyrk rozumiany jest tutaj raczej jako arena różnego rodzaju widowisk, przeznaczony był głównie na wyścigi rydwanów; widzów najbardziej emocjonowało igranie woźniców ze śmiercią, gdyż wypadki i śmierć na torze wyścigowym nierzadko towarzyszyły zawodom; por. Śrutwa, Widowiska epoki klasycznej, s. 47-48; Słapek, Sport i widowiska, s. 219.

${ }^{57}$ Obszerną bibliografię poświęconą tej tematyce zamieszcza w swoim artykule S. Longosz (Chrześcijańskie widowiska zastępcze w propozycji Ojców Kościoła, VoxP 37:2017, t. 67, 303-304), wskazując, że widowiska te w ocenie Ojców Kościoła miały charakter niemoralny i idolatryczny.

${ }^{58}$ Por. tamże, s. 305; Słapek, Sport $i$ widowiska, s. 190.

${ }^{59}$ Augustinus Hipponensis, Sermo 301a, 7, NBA 33, 482: „Comparate huic sancto spectaculo voluptates et delicias theatrorum. Ibi oculi inquinantur, hic corda mundantur; hic laudabilis est spectator, si fuerit imitator; ibi autem et spectator turpis est, et imitator infamis", tłum. własne.

${ }^{60}$ Por. Śrutwa, Widowiska epoki klasycznej, s. 53. 
Istotna w myśli kaznodziei jest kwestia naśladownictwa: każdy staje się tym, co sam podziwia. Podziwiając mimów, aktorów teatralnych, walczących gladiatorów, łowców, woźniców rydwanów, widzowie stają się im podobni: zajmują się kultem i zachwytem własnego ciała, oddają się rozpuście i wyuzdaniu, poddają się namiętnościom, igrają ze śmiercią, oddają cześć bożkom, skłaniają się ku bałwochwalstwu i idolatrii. Ci, którzy zwracają się ku męczennikom, stają się ich naśladowcami w wierności, wytrwałości, męstwie, odwadze i zapatrzeniu w wieczną szczęśliwośćć ${ }^{61}$.

Tok rozumowania Augustyna wynikał z jego osobistych doświadczeń i przemyśleń. Jego zdaniem, dusza człowieka i jej wieczny los zasługują na daleko większą uwagę niż doczesne doświadczenia i przyjemności związane z ciałem. Zmysły, instynkty, odruchy, potrzeby cielesne, piękno i siła ciała, tak eksponowane w czasie widowisk, prowadzą w ślepy zaułek i należy je przezwyciężać. W konsekwencji zatem, Augustyn proponował zastępowanie uciech doczesnych spektaklami duchowymi, których przykładem były walki toczone przez męczenników, wśród których znaleźli się również bracia Machabejscy ${ }^{62}$.

Trudno powiedzieć, na jaką skalę w czasach Augustyna borykano się jeszcze z problemem gorszących widowisk. W kazaniu wygłoszonym w Bulla Regia wskazywał na problem w tymże mieście, ale jednocześnie podawał Hippone jako przykład miasta, gdzie praktyki te prawie zupełnie ustały. Usprawiedliwiał Kartaginę, której mieszkańcy odznaczali się dużą różnorodnością religijną, ale potępiał miasteczko na wskroś chrześcijańskie, jako dające gorszący przykład przybyszom ${ }^{63}$.

Kult braci Machabejskich i ich matki rozwinął się w IV w. w Antiochii nad Orontesem i został przejęty w tym mieście przez chrześcijan od wyznawców judaizmu. Dość szybko stał się popularny także na Zachodzie, o czym świadczą zachowane homilie św. Augustyna. Trudno jednak ustalić na ich podstawie, a także innych dzieł biskupa Hippony, w jaki sposób kult ten dotarł w te rejony. Wspomnienie męczenników obchodzone było 1 sierpnia i z tej okazji głoszono tradycyjne homilie. Augustyn, uzasadniając chrześcijańską cześć oddawana postaciom Starego Testamentu, podkreślał brak zainteresowania nimi przez wyznawców judaizmu, a także ich przynależność do ludu Bożego, który - choć pośrednio - to jednak był ludem samego Chrystusa. Męczennicy Machabejscy wyznali swą wiarę w sposób nie bezpośredni, ale jak najbardziej prawowierny, gdyż oddali swe życie za prawo, które Chrystus wypełnił.

${ }^{61}$ Por. Augustinus Hipponensis, Sermo 301a, 7, NBA 33, 482-484. Zob. E. Stanula, Widowiska w ocenie Ojców Kościoła, SaeCh 2 (1995), nr 1, 13.

${ }^{62}$ Por. Słapek, Sport $i$ widowiska, s. 190.

${ }^{63}$ Por. Augustinus Hipponensis, Sermo 301a, 7, NBA 33, 484. Zob. Śrutwa, Widowiska epoki klasycznej, s. 54. 
Kaznodzieja szczególnie doceniał postawę matki siedmiu braci, która nie tylko musiała oglądać śmierć swoich synów, ale także wspierała ich w powziętym postanowieniu i sama oddała życie. W ten sposób, dla Augustyna, stała się symbolem Kościoła, który nie tylko w chrzcie rodzi swe dzieci, ale także towarzyszy im nieraz w męczeńskim świadectwie wiary. Męczeńska śmierć braci i ich matki przedstawiana jest przez duszpasterza jako swego rodzaju chrześcijańskie widowisko, w opozycji do rozrywek pogańskich, godne nie tylko udziału, ale i naśladowania. Kult braci Machabejskich stanowił dla biskupa zatem okazję do piętnowania niegodnych chrześcijanina postaw, zachętę do pogłębienia chrześcijańskiej duchowości i motywacji wierności Chrystusowi, wzywał do szczerego świadectwa wiary. Choć obecnie kult ten praktycznie zanikł, warto odwoływać się do tych starotestamentalnych postaci i sięgać do teologii ich męczeństwa wypracowanej przez Ojców.

\section{THE MATYRDOM AND WORSHIP OF THE MACCABEAN BROTHERS IN THE TEACHING OF ST. AUGUSTINE}

\section{(Summary)}

The article presents the place of martyrdom of both the seven Maccabean brothers and their mother, and the adoration of them according to the Bishop Augustine of Hippo. The worship developed in the 4th century and it also reached Africa. However, it demanded justification, due to the Old Testament character of the revered people. The Bishop provided an opportunity to present the essence of Christian martyrdom and loyalty to Christ and His people, to emphasize the value of the testimony and its authenticity. He also encouraged to polemics with Judaism and some of the pagan practices which were sometimes taken also by the Christians.

Key words: martyrdom, Augustine of Hippo, Antioch on the Orontes, Maccabean brothers, pastoral ministry, Church.

Słowa kluczowe: męczeństwo, Augustyn z Hippony, Antiochia nad Orontesem, bracia Machabejscy, duszpasterstwo, Kościół.

\section{BIBLIOGRAFIA}

\section{Źródła}

Augustinus Hipponensis, De civitate Dei, ed. B. Dombard - A. Kalb, CCL 47-48, Turnholti 1955, thum. W. Kornatowski: Święty Augustyn, O Państwie Bożym, t. 1-2, Warszawa 1977.

Augustinus Hipponensis, Enarrationes in Psalmos, ed. E. Dekkers - J. Fraipont, CCL 38-40, Turnholti 1956, tłum. J. Sulowski: Św. Augustyn, Objaśnienia Psalmów, PSP 37-42, Warszawa 1987.

Augustinus Hipponensis, Sermones, NBA 29-35, Roma 1979-2002. 
Tertullianus, Apologeticum, ed. E. Dekkers, CCL 1, Turnholti 1954, 77-171, tłum. J. Sajdak: Tertulian, Apologetyk, POK 20, Poznań 1947.

\section{Opracowania}

Adamiak S., Żydzi w rzymskiej Afryce Pólnocnej, BPTh 7/1 (2014) 97-113.

Baslez M.-F., Prześladowania w starożytności. Ofiary, bohaterowie, męczennicy, tłum. E. Łukaszczyk, Kraków 2009.

Brown P., Kult świętych. Narodziny i rola w chrześcijaństwie łacińskim, tłum. J. Partyka, Kraków 2007.

FiliPCZAK P., Antiochia nad Orontesem. Funkcjonowanie miasta i życie jego mieszkańców w IV wieku, w: Świat rzymski w IV wieku, red. P. Filipczak - R. Kosiński, Kraków 2015, 253-306.

Harrgington W.J., Klucz do Biblii, thum. J. Marzęcki, Warszawa 1982.

Hoek A. van DEN, Execution as Entertainment: The Roman Context of Martyrdom, StPatr 60 (2013) 73-100.

Homerski J., Kanon Ksiag Świętych, w: Wstęp ogólny do Pisma Świętego, red. J. Szlaga, Warszawa 1986, 69-97.

KaczmareK T., „,Seges Ecclesiae”. Eklezjalny wymiar męczeństwa w nauczaniu św. Augustyna, Toruń 2010.

KамсZук W., Kult świętego Szczepana w duszpasterstwie biskupa Augustyna z Hippony, SSHT 49/2 (2016) 311-331.

Longosz S., Chrześcijańskie widowiska zastępcze w propozycji Ojców Kościoła, VoxP 37 (2017) t. 67, 303-360.

Naumowicz J., Chrześcijański kult męczenników machabejskich w Antiochii, w: Byzantina Europaea. Ksiega jubileuszowa ofiarowana profesorowi Waldemarowi Ceranowi, red. M. Kokoszko - M.-J. Leszka, Łódź 2007, 431-447.

OżóG M., Przejęcie przez chrześcijan antiocheńskiego martyrium Machabeuszy, PrzRel 228 (2008) $\mathrm{nr}$ 2, 3-11.

Rampolla M., Martyre et sépulture des Machabées, trad. T.P.H. Lemonnier, „Revue de l'art chrétien" 42 (1899) 290-305, 377-392, 457-465.

RuBinKIEwICZ R., Jabne, EK VII 638-639.

SŁapek D., Sport i widowiska w świecie antycznym, Kraków - Warszawa 2010.

Stanula E., Widowiska w ocenie Ojców Kościoła, SaeCh 2 (1995) nr 1, 7-16.

Szczur P., Rola „zmystów wiary” w zrozumieniu sakramentów inicjacji chrześcijańskiej wedtug Cyryla Jerozolimskiego, VoxP 34 (2014) t. 61, 297-310.

Szczur P., Rola postrzegania duchowego w nauczaniu katechetycznym Jana Chryzosto$m a$, VoxP 34 (2014) t. 62, 493-504.

ŚRUTWA J., Widowiska epoki klasycznej w ocenie Kościoła afrykańskiego II-V wieku, RTK 27 (1980) z. 4, 43-56.

Terka M., Nauczanie św. Augustyna o Żydach w świetle „Enarrationes in Psalmos”, VoxP 32 (2012) t. 57, 677-698.

Wojciechowski M., Czwarta Księga Machabejska. Żydowski traktat stoicki o potędze rozumu udowodnionej przez męczeństwo. Wprowadzenie, w: M. Wojciechowski, Apokryfy z Biblii greckiej, Rozprawy i Studia Biblijne 8, Warszawa 2001, 97-115. 